\title{
Cross-cultural adaptation of a quality of life questionnaire for individuals with oral potentially malignant disorders in the Brazilian context
}

\author{
Igor F. B. de Almeida', Kátia S. Freitas ${ }^{1}$, Deybson B. de Almeida', Aminne O. da S. Bastos', \\ Mariane T. D. Farias², Márcio C. Oliveira'
}

1. Universidade Estadual de Feira de Santana, Departamento de Saúde, Bahia, Brasil.

2. Universidade Federal da Bahia, Escola de Enfermagem, Bahia, Brasil.

\begin{abstract}
The aim of this article is to describe the cross-cultural adaptation of a quality of life (QoL) questionnaire for individuals with potentially malignant oral diseases (OPMD) in the Brazilian context. This methodological study consisted of the following stages of content validation process: (1) Conceptual and item equivalence: stage during which a comprehensive literature review on the construct was performed; (2) Semantic equivalence. The extensive literature review showed that the questionnaire enables evaluation of QoL, and that domains and items are also considered and relevant to the Brazilian context. Semantic equivalence was evaluated as satisfactory by a committee of judges. The scope of the domains was analyzed according to the agreement rate and presented results equal to or greater than $84 \%$. The general Content Validity Calculation
\end{abstract}

$(C V C)$ was 0.84 for clarity and 0.92 for representativeness. Of the 20 items, 18 presented CVC values above 0.8. The indicators for content validation, pre-test and operational equivalence indicate that the Brazilian version of the OPMD QoL questionnaire is a promising instrument and a tool that seems valid to evaluate the quality of life of people with oral potentially malignant disorders. As a next step, it is important to measure equivalences to evaluate the psychometric properties of this instrument.

Received: January 2021: Accepted: February 2021.

Keywords: validation study - questionnaires - quality of life leukoplakia - cheilitis.

\section{Adaptação transcultural do questionário de qualidade de vida para indivíduos com desordens orais potencialmente malignas para o contexto brasileiro}

\begin{abstract}
RESUMO
Este artigo objetiva adaptar transculturalmente um questionário de qualidade de vida para indivíduos com doenças orais potencialmente malignas para o contexto brasileiro. Este estudo metodológico consistiu nas seguintes etapas do processo de validação de conteúdo: (1) Equivalência conceitual e de itens - etapa em que foi realizada uma ampla revisão da literatura sobre o construto; (2) Equivalência semântica. A extensa revisão da literatura mostrou que o questionário permite avaliar a $Q V e$ que os domínios e itens também são considerados e relevantes para o contexto brasileiro. A equivalência semântica foi avaliada pelo comitê de juizes de forma satisfatória. A análise do escopo dos domínios foi realizada pela taxa de concordância e apresentou resultados iguais ou superiores a 84\%. Para a
\end{abstract}

análise de clareza e representatividade, o resultado do cálculo geral do Cálculo de Validade de Conteúdo (CVC) foi de 0,84 e 0,92 respectivamente. Dos 20 itens, 18 apresentaram valores de IVC acima de 0,8. Os indicadores de validação de conteúdo, pré-teste e equivalência operacional indicam que a versão brasileira do QoL-OPMD é um instrumento promissor e que parece válido para avaliar a qualidade de vida de pessoas com doenças orais potencialmente malignas. Como próximo passo, é importante avaliar as propriedades psicométricas desse instrumento.

Palavras-chave: estudos de validação - questionários qualidade de vida - leucoplasia - queilite. 


\section{INTRODUCTION}

Oral Potentially Malignant Disorders (OPMD) are clinical manifestations that present a risk of progression to cancer and can significantly impair quality of life $(\mathrm{QoL})^{1,2}$. Mouth cancer is a public health problem in several countries around the world, with an estimated annual incidence of 274,000 new cases and 128,000 deaths. In Brazil, for the years 2020-2022, there were an estimated 11,180 cases in men and 4,010 in women. Among all cancers, it ranks $5^{\text {th }}$ for men and $13^{\text {th }}$ for women ${ }^{3}$.

The World Health Organization highlights the importance of prevention and early detection as decisive conditions for controlling oral cancer, and identifies the main OPMD as: leukoplakia, erythroplasia, oral lichen planus, actinic cheilitis and oral submucosal fibrosis ${ }^{4}$.

Recent studies indicate that patients with OPMD may present physical impairment and limitations, as OPMD cause pain, difficulties and limitations in speech, functional limitations in mouth opening and discomfort to eat ${ }^{1,5}$, which may compromise patients' quality of life (QoL). Improvement in QoL has thus become one of the expected outcomes of care practices and public policies in the fields of health promotion and disease prevention ${ }^{6,7}$.

To measure the degree ofimpairment of this important health indicator, the Quality-of-life questionnaire for patients with oral potentially malignant disorders (OPMD QoL questionnaire) was developed and validated in India to measure QoL in patients with OPMD by specifically assessing subjective perceptions of the impacts of OPMD on aspects of their daily lives. This questionnaire is a subjective indicator that aims to ascertain the measure of disability, discomfort and disadvantage attributed to the oral condition, through self-assessment ${ }^{2}$.

Developed by Jyothi Tadakamadla et $a .^{2}$, the questionnaire includes 20 items distributed among four factors: difficulties in diagnosis, physical impairment and limitations, social and psychological well-being and effects of treatment. The OPMD QoL questionnaire was validated in its context of origin, presenting favorable psychometric indices. Internal consistency measured by Cronbach's alpha coefficient was satisfactory $(\alpha=0.93)$. Stability measured through the re-test and verified by the intra-class correlation coefficient was also satisfactory $(\mathrm{r}=0.85)$. No other adaptations of this instrument were identified in other contexts.
An extensive literature review using the terms Quality of Life and OPMD in Lilacs, Scielo and Medline databases only found seven articles for analysis, thus confirming the existing gap due to low production. All these publications came from foreign journals, and the studies were conducted in India. Of the seven studies evaluated, only two addressed the production and validation of instruments whose objective was specifically to evaluate quality of life (QoL) in patients with OPMD.

The absence of tools in Portuguese for ascertaining quality of life in people with OPMD, and the need for a comprehensive approach in oral health practices that would include a subjective care perspective, create an imperative need in Brazil for a new measurement instrument that would be useful both clinically and epidemiologically. Thus, the aim of this article is to present the process of cross-cultural adaptation of a quality of life questionnaire for individuals with oral potentially malignant disorders (OPMD QoL questionnaire) in the Brazilian context.

\section{MATERIALS AND METHODS}

This research project was registered in the Brazil Platform and submitted for evaluation to the Human Research Ethics Committee (REC) at the State University of Feira de Santana, being approved under opinion number 3.578.351 and CAAE: 156224619.1.0000.0053.

The cross-cultural adaptation proposed herein is part of the universalist model of Herdman et al. ${ }^{8}$ and Reichenheim and Moraes 9 . Our methodological study focused on adapting the quality of life questionnaire for individuals with oral potentially malignant disorders (OPMD QoL questionnaire).

The OPMD QoL questionnaire consists of 20 items to assess QoL. The answers are scored on a fivepoint Likert scale $(0-4)$, in which $0=$ not at all; $1=$ a little; $2=$ somewhat; $3=$ quite a bit; $4=$ very much. The summary score of the questionnaire ranges from 0 to 80 , with a higher score indicating lower quality of life ${ }^{2}$.

\section{Conceptual and item equivalence}

After securing permission from the author of the original instrument, a comprehensive literature review was conducted on the construct quality of life in patients with OPMD and the relevance of this topic, from the domains and items of the OPMD QoL questionnaire, to the Brazilian context. 


\section{Semantic equivalence assessment}

Semantic equivalence was assessed in seven stages: translation, synthesis, retranslation, synthesis, evaluation by the author of the original instrument, review by a committee of expert judges and evaluation by the target audience through pre-test. The instrument was translated individually by two Brazilian translators, qualified in English, who were sent a letter of invitation by e-mail. The first two translations of the questionnaire (T1 and T2), they were synthesized by consensus among the study researchers to ensure that the items would be understood by the target population (synthesis of translations).

The synthesis version of the questionnaire in Portuguese was retranslated into English by two qualified translators whose mother tongue was English. This provided two versions of the questionnaire called back-translations - B1 and B2. The two back-translations were evaluated once again by the research team and a single version was produced (synthesis of back-translations), thus generating another synthesis (preliminary version), which was forwarded to the author of the original instrument for evaluation. Subsequently, it was initially evaluated by a group of 13 judges comprising professional specialists in the fields of health and linguistics.

The expert judges for this stage were found by searching the Lattes Curriculum platform for scientific productions related to questionnaire preparation, cross-cultural adaptation and psychometric assessment of health instruments. Subsequently, the Snowball technique was used to find other judges up to the maximum number established for this research. In the Snowball technique, the judge contacted through the Lattes Curriculum suggested another researcher who could respond to the instrument. A defined protocol was followed for the indicated researcher, in the following sequence: (1) Invitation letter; (2) Informed Consent Form for expert judges and (3) Evaluation instrument for expert judges.

A specific evaluation instrument was created for the analysis to be performed by the 13 expert judges. It was organized in two stages: (1) evaluation of the domains and their content regarding the scope of the construct, and (2) evaluation of each item in the OPMD QoL questionnaire regarding clarity and representativeness in the Brazilian context. The judges used a scale of 1 to 4 to assess the level of adequacy of language clarity and representativeness for the Brazilian context (evaluation of clarity, $1=$ very unclear; $2=$ unclear; $3=$ clear; $4=$ very clear; evaluation of representativeness, $1=$ not representative; $2=$ requires thorough review to be representative; $3=$ requires little review to be representative; $4=$ representative).

In the first stage, the judges verified whether the structure of the domain and its content were adequate and whether the content in each domain was representative in the Brazilian context. The agreement rate was calculated as the ratio between the number of judges who agreed and the total number of judges who participated, multiplied by 100 , following the recommendations of Alexandre et al. ${ }^{10}$.

Then the clarity and representativeness of the 20 individual items were analyzed using the content validity calculation (CVC). The aim of the CVC is to identify items that may not be appropriate to the objectives of the instrument. It analyzes the agreement among the expert judges. For this study, the CVC was calculated for each item in the instrument $\left(\mathrm{CVC}_{\mathrm{f}}\right)$ and for the instrument as a whole $\left(\mathrm{CVC}_{\mathrm{t}}\right) . \mathrm{CVC}$ was considered appropriate if it was above $0.70^{11}$.

After analyzing the evaluation performed by the specialists, adjustments were made, obtaining the preliminary version of the OPMD QoL questionnaire to be evaluated by the target population through the pre-test stage, of which the aim was to identify any problems of interpretative order. Participants in the pre-test were a group of patients with a clinical diagnosis of OPMD and histopathological epithelial dysplasia or oral lichen planus. They were interviewed by a dentist who had been previously trained for the application of the sociodemographic data collection questionnaire and a specific evaluation instrument for the target population that also contained the OPMD QoL questionnaire.

The interviewer held individual conversations with the participants. Each item was read, and the participant was asked to paraphrase what he/ she understood about it and to identify any words or terms he/she did not understand. The participant answered the question first, and the interviewer marked one of the four options provided in the instrument according to the following scores: $0=$ not at all; $1=$ a little; $2=$ half the times; $3=$ a lot; 
$4=$ completely. After this stage, the participant responded by checking YES or NO, if he/she considered the item important to evaluate his/her quality of life and for the clarity of the item. The pretest instrument included a blank field for suggestions or observations. In case of misunderstanding of any word or item, the participant was asked to suggest expressions that would improve understanding.

After completing the pre-test, the group's agreement rate was calculated as the percentage of each domain according to the following formula: $\%$ of agreement $=$ number of participants who agreed, divided by the total number of participants, multiplied by 100 .

\section{Operational equivalence}

Operational equivalence was analyzed with the same group of pre-test participants, using a specific evaluation instrument. The aim of this phase was to obtain information for refining the adapted instrument by asking about presentation format, questions, instructions, application location, application mode and OPMD QoL questionnaire response alternatives.

\section{RESULTS}

Tables 1, 2, 3 and 4 show the original version, syntheses of the translations and back-translations, version evaluated by the judges and final version of the OPMD QoL questionnaire.

Regarding the analysis of the scope of the domains, the agreement rate was calculated, providing the following results: (I) for the difficulties in diagnosis domain, the agreement rate was $92 \%$; (II) for the physical impairment and limitations domain, the agreement rate was $88 \%$; (III) for the psychological and social well-being domain, it was $84 \%$ (IV) and for treatment effects on daily activities, it was $84 \%$. To analyze the clarity and representativeness of the items, the CVC was calculated initially for each item and, at the end, for the whole instrument. The general CVC of the OPMD QoL questionnaire was 0.84 for clarity and 0.92 for representativeness. Table 5 shows the CVC results for clarity and representativeness of the 20 items.

In the pre-test phase, the analysis of participant sociodemographic data showed: mean age 61.5 years; $83.3 \% \quad(\mathrm{n}=10)$ self-reported as brown or black and $16.7 \%(n=2)$ as white; $50 \%(n=6)$ of the respondents had only incomplete primary school, 25\% $(n=3)$ secondary school, 16.6\% $(n=2)$ complete primary school and $8.3 \%(\mathrm{n}=1)$ without schooling. Regarding type of OPMD, the following indices were identified: $50 \%(\mathrm{n}=6)$ oral leukoplakia; $24.9 \%(n=3)$ lichen planus (one erosive and two reticular); $16.6 \%$ actinic cheilitis $(\mathrm{n}=2) ; 8.3 \%$ $(n=1)$ erythroleukoplakia, no patient presented oral submucosal fibrosis. Regarding habits, 75\% ( $\mathrm{n}=9)$ were nonsmokers and 25\% $(\mathrm{n}=3)$ smokers; $83.4 \%$ $(n=9)$ non-alcoholic and 16.6\% $(n=3)$ alcoholics.

The average response time of the instrument was

Table 1. Original version, synthesis of translations and back-translations, version evaluated by the judges and final version of the OPMD QoL questionnaire (domain 1 - difficulties in diagnosis).

\section{Original Version (items 1 to 3 )}

How difficult was it for you to get your mouth condition diagnosed?

How much did the need to visit many doctors for getting your mouth condition diagnosed affect daily life activities?

How stressful was it for you to take a variety of treatments before being diagnosed with your mouth condition?
Synthesis of translations (T1 and T2)

Que dificuldade você teve para ter o diagnóstico da sua condição bucal?

A necessidade de visitar muitos médicos para ter o diagnóstico de sua condição bucal afetou quanto as atividades da sua vida diária?

Quão estressante foi para você se submeter a uma variedade de tratamentos antes de ser diagnosticado com a sua condição bucal atual?

\section{Synthesis of back- translations (B1 and B2)}

How difficult was it for you to have your oral condition diagnosed?

To what extent did the need to visit many doctors in order to get a diagnosis for your oral condition affect your daily routine?

How stressful was it to undergo a variety of treatments before being diagnosed with your current oral condition?

\section{Version evaluated by the judges}

Que dificuldade você teve para ter o diagnóstico da sua condição bucal?

A necessidade de visitar muitos médicos para ter o diagnóstico de sua condição bucal afetou quanto as atividades da sua vida diária?

Quão estressante foi para você se submeter a uma variedade de tratamentos antes de ser diagnosticado com a sua condição bucal atual?

\section{Final version of the QOL-OPMD}

Foi difícil para você conseguir o diagnóstico da sua condição bucal?

A necessidade de visitar muitos dentistas para ter o diagnóstico de sua condição bucal afetou as atividades da sua vida diária?

Foi estressante para você se submeter a vários tratamentos antes de ser diagnosticado com a sua condição bucal atual? 
Table 2. Original version, synthesis of translations and back-translations, version evaluated by the judges and final version of the OPMD QoL questionnaire (domain 2 - physical impairment and limitations).

Original Version
(items 4 to 10)

How much pain and agony does your mouth condition cause you?

How much burning sensation do you experience while having spicy food?

How difficult is it for you to open your mouth widely?

How much is your ora condition causing you to limit your desired foods?

How much is your mouth condition limiting you from enjoying your meals?

How much does your mouth condition affect your taste sensation?

How much dryness do you feel in your mouth?
Synthesis of translations

( $\mathrm{T} 1$ and $\mathrm{T} 2$ )

Quanta dor e agonia a sua condição bucal causa em você?

Quanta sensação de queimor você experimenta quando come comida picante?

Quão difícil é para você abrir a sua boca de forma bem ampla?

Quanto a sua condição bucal limita você de comer os alimentos que deseja?

Quanto a sua condição bucal limita você de aproveitar as suas refeições?

Quanto a sua condição bucal afeta seu paladar?

Quão seca você sente a sua boca?
Synthesis of backtranslations (B1 and B2)

How much pain and agony does your mouth condition cause you?

How much burning sensation do you feel when eating spicy food?

How difficult is it for you to open your mouth wide?

To what extent does your oral condition stop you from eating what you want?

To what extent does your oral condition stop you from enjoying your meals?

To what extent does your oral condition affect your sense of taste?

How much do you feel that your mouth is dry?

\section{Version evaluated by the judges}

Quanta dor e agonia a sua condição bucal causa em você?

Quanta sensação de queimor você experimenta quando come comida picante?

Quão difícil é para você abrir a sua boca de forma bem ampla?

Quanto a sua condição bucal limita você de comer os alimentos que deseja?

Quanto a sua condição bucal limita você de aproveitar as suas refeições?

Quanto a sua condição bucal afeta seu paladar?

Quão seca você sente a sua boca?
Final version of the QOL-OPMD

Sua condição bucal causa dor em você?

Quanta sensação de queimação você sente quando come comida picante, quente ou ácida?

É difícil para você abrir a sua boca de forma bem ampla?

Sua condição bucal limita você de comer os alimentos que mais gosta?

Sua condição bucal limita você de aproveitar suas refeições?

Sua condição bucal afeta o sabor dos alimentos?

Você sente a sua boca seca?
10 minutes, and the mode of administration was the interview. The instrument was well accepted by the participants. It is important that no respondent considered participation to be tiring, possibly because the instrument is considered short, with only 20 items. All items were well understood and considered useful for QoL assessment by the respondents. No participant suggested modifications to the instrument.

All participants considered the answer options for the 20 items in the questionnaire using the 5-point Likert scale (in which the $0=$ not at all; $1=$ a little; $2=$ somewhat; $3=$ quite a bit; $4=$ very much) to be adequate and there was no suggestion of change.

The respondents were also asked to evaluate whether the 20 items in the OPMD QoL questionnaire were relevant/important for assessing quality of life and whether they were clear enough to understand. All respondents $(100 \%)$ considered all items to be both important and clear (i.e., checked YES for all items for both questions).

In the operational equivalence stage, the participants answered the questions related to questionnaire format, their opinion of the items, the instructions provided during the interview, the place of pre-test, in relation to the way the instrument was applied and finally the participant's opinion on the alternatives of the questionnaire. The participants considered all these points to be adequate, thus generating $100 \%$ positive responses.

\section{DISCUSSION}

The cross-cultural adaptation (CCA) of the OPMD QoL questionnaire followed the stages of content validation recommended by the literature, demonstrating the importance of each item in the instrument in measuring quality of life of people with OPMD ${ }^{8-12}$.

Thus, the first stage of the OPMD QoL questionnaire CCA process, in the evaluation of conceptual and item equivalence ${ }^{8,9}$, was the extensive, in-depth literature review, which showed that the original instrument and its conceptual bases were also relevant and applicable in the Brazilian context. 
Table 3. Original version, synthesis of translations and back-translations, version evaluated by the judges and final version of the OPMD QoL questionnaire (domain 3 -psychological and social well-being).

\section{Original Version (items 11 to 17)}

How frustrated are you because of your oral condition?

How depressed or low do you feel because of your mouth condition?

In general, how much is your mouth

condition affecting your relationship with

family and friends?

How much is your mouth condition affecting your satisfaction with life?

How scared are you about the possibility of your oral condition turning into cancer

How scared are you about the outcome of this condition affecting your life?

How embarrassing is it for you to eat foods at parties, functions, or other social gatherings?

\section{Synthesis of transla- tions (T1 and T2)}

Quão frustrado você está por causa de sua condição bucal?

Quão deprimido ou para baixo você se sente por causa da sua condição bucal?

Em geral, quanto a sua condição bucal está afetando seu relacionamento com a família e os amigos?

Quanto a sua condição bucal está afetando a sua satisfação com a vida?

Quão assustado você está com a possibilidade de sua condição bucal se transformar em câncer?

O quanto assustado você está com o resultado dessa condição afetar a sua vida?

O quanto é embaraçoso para você comer alimentos em festas, eventos ou outras reuniões sociais?

\section{Synthesis of \\ back-translations \\ (B1 and B2)}

How frustrated do you feel because of your oral condition?

How depressed or low do you feel because of your oral condition?

In general, to what extent is your oral condition affecting your relationship with Family and friends?

To what extent is your oral condition affecting your life satisfaction?

How frightened are you with the possibility of your oral condition turning into cancer?

How scared are you about the outcome of this condition affecting your life?

How embarrassing is it for you to eat foods at parties, functions, or other social gatherings?

\section{Version evaluated by the judges}

Quão frustrado você está por causa de sua condição bucal?

Quão deprimido ou para baixo você se sente por causa da sua condição bucal?

Em geral, quanto a sua condição bucal está afetando seu relacionamento com a família e os amigos?

Quanto a sua condição bucal está afetando a sua satisfação com a vida?

Quão assustado você está com a possibilidade de sua condição bucal se transformar em câncer?

O quanto assustado você está com o resultado dessa condição afetar a sua vida?

O quanto é embaraçoso para você comer alimentos em festas, eventos ou outras reuniões sociais?

\section{Final version of the QOL-OPMD}

Sua condição bucal te deixa frustrado?

Você se sente deprimido ou para baixo por causa de sua condição bucal?

Sua condição bucal está afetando seu relacionamento com a família e os amigos?

Sua condição bucal está afetando a sua satisfação com a vida?

Você está assustado com a possibilidade de sua condição bucal se transformar em câncer?

Você está com medo dessa condição afetar sua vida?

É desagradável para você comer alimentos em festas, eventos ou outras reuniões sociais?

Table 4. Original version, synthesis of translations and back-translations, version evaluated by the judges and final version of the OPMD QoL questionnaire (domain 4 - effects of treatment on daily life).

\section{Original Version}

How much pain do you experience with treatment of your oral condition?

How satisfied are you with the effectiveness of treatment for your mouth condition?

How much are your treatment appointments affecting your daily schedule?
Synthesis of translations ( $\mathrm{T} 1$ and T2)

Quanta dor você sente com o tratamento de sua condição bucal?

Quão satisfeito(a) você está com a eficácia do tratamento para a sua condição bucal?

Quanto as suas consultas de tratamento estão afetando a sua programação diária?
Synthesis of backtranslations (B1 and B2)

Quanta dor você sente ao tratar sua condição bucal?

How satisfied are you with the result of the treatment for your oral condition?

Até que ponto suas consultas estão afetando sua rotina diária?
Version evaluated by the judges

Quanta dor você sente com o tratamento de sua condição bucal?

Quão satisfeito(a) você está com a eficácia do tratamento para a sua condição bucal?

Quanto as suas consultas de tratamento estão afetando a sua programação diária?
Final version of the QOL-OPMD

Você sente dor devido ao tratamento de sua condição bucal?

Você está satisfeito com o resultado tratamento da sua condição bucal?

Suas consultas de tratamento estão afetando a sua programação diária? 


\begin{tabular}{|c|c|c|c|c|c|}
\hline Item & CVCfe & CVCfr & Item & CVCfc & CVCfr \\
\hline 1 & 0.74 & 0.95 & 11 & 0.83 & 0.89 \\
\hline 2 & 0.75 & 0.91 & 12 & 0.83 & 0.91 \\
\hline 3 & 0.79 & 0.93 & 13 & 0.89 & 0.93 \\
\hline 4 & 0.77 & 0.89 & 14 & 0.87 & 0.91 \\
\hline 5 & 0.74 & 0.88 & 15 & 0.89 & 0.95 \\
\hline 6 & 0.87 & 0.91 & 16 & 0.77 & 0.85 \\
\hline 7 & 0.85 & 0.95 & 17 & 0.85 & 0.91 \\
\hline 8 & 0.81 & 0.83 & 18 & 0.91 & 0.95 \\
\hline 9 & 0.85 & 0.91 & 19 & 0.87 & 0.95 \\
\hline 10 & 0.95 & 0.99 & 20 & 0.81 & 0.91 \\
\hline \multicolumn{6}{|c|}{ CVCtc $=0.84 /$ CVCtr $=0.92$} \\
\hline \multicolumn{6}{|c|}{$\begin{array}{l}\text { CVCfc = Final Content Validity Calculation of clarity } / \text { CVCfr }= \\
\text { Final Content Validity Calculation of representativeness } / \mathrm{CVCtc} \\
=\text { total Content Validity Calculation of clarity of the OPMD QoL } \\
\text { questionnaire } / \text { CVCtr }=\text { total Content Validity Calculation of } \\
\text { representativeness of the OPMD QoL questionnaire. }\end{array}$} \\
\hline
\end{tabular}

Moreover, the individual evaluation of each item and its inclusion in the questionnaire showed that the questionnaire contemplated all aspects that could influence the quality of life of individuals with OPMD, so the 20 items in the original instrument were maintained, with only language adjustments to ensure the target audience would understand, without conceptual modifications or addition of new items.

The analysis of the instrument performed by the group of expert judges and target population was essential to the adequacy of the OPMD QoL questionnaire items for use in the Brazilian context. The group of judges included specialists in the areas of Stomatology, Oral Pathology, Dental Clinic, Nursing, Medicine and Linguistics, thereby ensuring careful, pluralistic evaluation, offering information that would broaden the universe of suggestions and critiques for semantic improvement of the questionnaire.

Corroborating the need for diversity of qualification among the members of the committee of judges, Beaton et al. ${ }^{12}$ and Rubio et al. ${ }^{13}$ highlight that a group of judges should be multidisciplinary, including specialists such as health professionals, language professionals and specialists in methodology, i.e., it should consist of specialists in the area of knowledge of the instrument.

It is important to highlight that the instructions sent to the expert judges for the assessment of the OPMD QoL questionnaire, in a specific instrument ${ }^{13}$, were of paramount importance for adequate evaluation of the scope of the domains, clarity and relevance of the items. The judges considered that all four domains in the OPMD QoL questionnaire were comprehensive when considering the concepts and aspects of QoL of individuals with OPMD in the Brazilian context, thus achieving conceptual and item equivalence. For all domains, the agreement rates were higher than or equal to $84 \%$.

For the first domain, difficulties in diagnosis, comprising items 1 to 3 , the agreement rate was $92 \%$, and it was therefore considered adequate. It is important to highlight that OPMD is a group of chronic disorders that have an increased potential for malignant transformation, so early diagnosis is fundamental for maintaining patients' health ${ }^{1,14}$. However, a study conducted by Tadakamalda et $a l .{ }^{2,6}$, revealed that the pre-diagnosis phase was very traumatic for most of the interviewed patients, as they had to perform many visits and undergo different types of treatment, usually without relief. Corroborating the issue of difficult diagnosis of OPMD, a study conducted by Silva et $a l .{ }^{15}$ and Fanaras ${ }^{16}$ found that some professionals had little knowledge on what to do about those disorders. However, younger participants, students and more recent graduates demonstrated better knowledge of those diseases.

The second domain, physical impairment and functional limitations, comprises items 4 to 10 of the OPMD QoL questionnaire, which together propose to evaluate subjective issues such as pain, burning sensation, difficulty in opening the mouth, limitations in eating and dryness sensation. For this domain, the agreement rate among the judges was $88 \%$, so it was considered adequate.

Tadakamadla et al. ${ }^{6}$, in a study on 150 people diagnosed with OL, OLP and OSF, using the OPMD QoL questionnaire, found as the most recurrent complaints the sensation of burning, difficulty in mouth opening and roughness in the cheek mucosa and pain. The same study showed that patients with OLP have the worst QoL scores, especially for the domain of physical impairment and functional limitations, when compared to patients with OL and OSF.

Corroborating this perspective, Warnakulasurya ${ }^{17}$ found a decline in the QoL of patients with OLP, 
and the physical dimension and social disability presented higher values, thus, values such as these demonstrate that patients with OPMD who present pain require specific individualized treatment in an attempt to revert the picture to the asymptomatic profile.

The third domain, psychological and social wellbeing, comprises items 11 to 17 , which aim to evaluate issues related to frustration, depression, satisfaction, relationship with family and friends and concern about the malignant potential of disorders. For this domain, the agreement rate among the judges was $84 \%$.

It is important to report that a healthy oral cavity enables the individual to perform routine activities without physical and psychological limitations; however, any disorder of the oral cavity can reduce self-confidence and relational capacity, thus compromising the quality of life of affected individuals ${ }^{18}$.

Corroborating the above, Gondivkar et al. ${ }^{1}$, observed that, in a group of 305 people with OPMD, more than half presented affected social interaction and $82 \%$ showed psychological impact associated mainly with the risk of malignancy of the lesions. The same study also found that the greater the progression of the disease, the greater the psychological and social impacts on affected patients. Tadakamadla et al. ${ }^{2}$, observed that fear associated with the possibility of malignant transformation was predominant among the interviewed patients, because the term cancer is associated with fear and stigma, since it is considered a fatal disease for most people.

The fourth and final domain, effect of treatment on daily life, comprises the last three items, 18 to 20, which seek to assess the individual's satisfaction with the treatment of his/her oral condition, as well as to measure the impact on daily life. The agreement rate among judges was $84 \%$.

OPMD usually requires long-term treatment involving multiple treatment sessions and followup visits, with which patients often find it difficult to comply. Socioeconomic status greatly influences the maintenance of periodic visits. Furthermore, adverse effects such as nausea, swollen mouth, bad taste and smell, difficulty in spray application, dry mouth, sore throat, redness and occurrence of pseudomembranous candidiasis were reported by patients treated for some OPMD ${ }^{2,6,19}$.

As for OPMD QoL questionnaire items, some adjustments were made to the wording, including replacing certain words or expressions with others that were better understood or more suitable for the target culture. Changes in the wording of items are expected in this process of cultural adaptation of instruments in order to maintain semantic equivalence ${ }^{8-10,20}$.

For the content validity calculation $(\mathrm{CVC})$ related to clarity, only five items (1 (0.74), 2 (0.75), 4 (0.77), 5 (0.74), $16(0.77))$ scored slightly below 0.78 , thus requiring change, adopting the suggestions by the judges and the author Hernandez-Nieto ${ }^{11}$. This decision was based on the assumption described by Alexandre et al. ${ }^{10}$, in which the authors recommend changes in the wording of the items with the aim of improving understanding by the target population.

In the representativeness analysis, all items had a final CVC value greater than 0.78 . Nevertheless, it is important to highlight that item 8- How much is your mouth condition limiting you from enjoying your meals? - presented the lowest $\mathrm{CVC}$ value (0.83). It is worth noting that, although some judges suggested removing this item, the research committee decided to keep it, taking into account that through this question, the intention of the original instrument was to capture other subjective aspects related to the habit of eating and not just chewing. The question raised by some judges was the fact that this item may be similar to the previous item (7- How much is your oral condition causing you to limit your desired foods? - ).

In the evaluation phase by the target population during the pre-test, the participants who answered the questionnaire considered that it was fully understood and easily answered. Moreover, all participants considered that all 20 items were important for assessing quality of life. Semantic analysis showed that $100 \%$ of the pre-test participants considered that all items of the specific instrument for this stage were adequate, without suggesting any changes. This may be explained by the low level of education of the participants, of whom approximately $75 \%$ had only the elementary level of education.

The results of the operational equivalence phase showed that the participants responded affirmatively that the form, the instructions provided during the interview, the place where the pre-test was held, the way the instrument was applied and the response alternatives were adequate, thus generating 100\% acceptance. 
Despite its contributions, this study has some limitations, such as the performance of the committee of judges through electronic correspondence, which limited their discussions with the research team, and the low level of education of the pre-test participants, which may have reduced the possibilities of suggestions and improvements in the operational equivalence stage.

The results presented in this study demonstrate good acceptability of the OPMD QoL questionnaire to the respondents and, above all, may reflect effective cultural adequacy of the instrument for the target population. Thus, the final version of the instrument maintained the format and sequence of the items presented in the original version and was able to provide empirical validity.

\section{DECLARATION OF CONFLICTING INTERESTS}

The authors declared no potential conflicts of interest with respect to the research, authorship, and/or publication of this article.

\section{FUNDING}

None

\section{REFERENCES}

1. Gondivkar SM, Bhowate RR, Gadbail AR, Gaikwad RN, Gondivkar RS, Sarode SC, Sarode GS. Development \& validation of oral health related quality of life measure in oral submucous fibrosis. Oral Dis 2018;24:1020-1028.

2. Tadakamadla J, Kumar S, Laloo R, Johnson NW. Development and validation of a quality of life questionnaire for patients with potentially malignant oral disorders. Oral Surg Oral Med Oral Pathol Oral Radiol 2017;123:338-349.

3. Institute NC. Estimate - 2020-22 - Cancer Incidence in Brazil: INCA, 2020. URL: https://www.inca.gov.br/ incidenciadecancernobarsil

4. World Health Organization (WHO). Classification of Tumours. Pathology \& Genetics. Head and Neck Tumours. Lyon: International Agency for Research on Cancer (IARC) 2005;9-177.

5. Santosh RP, Yadav N, Al-Zoubi IA, Maragathavalli G, Sghaireen MG, Gudipaneni RK et al. Comparative study of the efficacy of newer antioxitands lycopene and oxitard in the treatment of oral submucous fibrosis. Braz ResPed Dent Integrated Clinic 2018;8:e4059.

6. Tadakamadla J, Kumar S, Lalloo R, Babu DBG, Johnson NW. Impact of oral potentially malignant disorders on quality of life. J Oral Pathol Med 2018;47:60-65.

7. Schuttinga JA. Quality of life from a federal regulatory perspective. In: Dimsdale JE, Baum A, edit o r s. Quality of life in behavioral medicine research. New Jersey: Lawrence Erlbaum Associates 1995;4:69.

8. Herdman M, Fox-Rushby J, Badia X. A modelo of
Thus, the present study adapted the Quality-oflife questionnaire for patients with oral potentially malignant disorders to the Brazilian context by following the steps recommended by the literature. The questionnaire meets the equivalences proposed in the process of cross-cultural adaptation regarding domains, clarity and understanding of the items, satisfactory instructions and representativeness.

The indicators of content validation, pre-test and operational equivalence indicate that the Brazilian version of the OPMD QoL questionnaire is a promising instrument and a tool that seems valid to evaluate the quality of life of people with oral potentially malignant disorders. As a next step, it is important to measure equivalences to evaluate the psychometric properties of this instrument.

\section{CORRESPONDENCE}

Ms. Igor Ferreira Borba de Almeida

Universidade Estadual de Feira de Santana

Av. Transnordestina, s/n, Núcleo de Câncer Oral, Feira de Santana, Bahia, Brasil.

borbadealmeidaigor@gmail.com

equivalence in the cultural adaptation of HRQoL instruments: the universalist approach. Qual Life Res 1998;7:323-335.

9. Reichenheim ME, Moraes CL. Operationalization of crosscultural adaptation of measurement instruments used in epidemiology. Rev Saúde Pública 2007;41:665-673.

10. Coluci MZ, Alexandre NM, Milani D. Construção de instrumentos de medida na área da saúde [Construction of measurement instruments in the area of health]. Cien Saude Colet. 2015 Mar;20:925-36.

11. Hernandez-Nieto RA. (2002). Contributions to Statistical Analysis Merida: Universidad de Los Andes 2002;119.

12. Beaton DE, Bombardier C, Guillemin F, Ferraz MB. Guidelines for the process of cross-cultural adaptation of self-report measures. Spine 2000;25:3186-3191.

13. Rubio DM, Berg-Weger M, Tebb SS, Lee S, Rauch S. Objectifying content validity: conducting a content validity study in social work research. Soc Work Res 2003;2794-105.

14. Lodi G, Franchini R, Warnakulasuriya S, Varoni EM, Sardella A, Kerr AR et al. Interventions for treating oral leukoplakia to prevent oral cancer. Cochrane Database Syst Rev. 2016;7: CD001829.

15. Silva LGD; Alves ML; Severo MLB; Medeiros, WKD; Ferreira, AM; Miguel, MCC; Silveira EJD. Malignant and Potentially Malignant oral Lesions: Level of Knowledge of Dentists and Dental Students.. Rev Bras Cancer 2018;64:35-43.

16. Fanaras N, Warnakulasuriya S. Oral Cancer Diagnosis in primary Care. Prim Dent J. 2016; 5:64-68.

17. Warnakulasuriya S. Clinical features and presentation of 
oral potentially malignant disorders. Oral Surg Oral Med Oral Pathol Oral Radiol 2018;125:582-590

18. Gomes AS, Abegg C. The impact of oral health on the daily performance of municipal waste disposal workers in Porto Alegre, Rio Grande do Sul, Brazil. Cad Saude Publica. 2007; 23:1707-1714.

19. Mello FW, Miguel AFP, Dutra KL, Porporatti AL,
Warnakulasuriya S, Guerra ENS, Rivero ERC. Prevalence of oral potentially malignant disorders: A systematic review and meta-analysis. J Oral Pathol Med. 2018;47:633-640.

20. Sampaio PF, Moraes CL, Reichenheim ME. Conceptual, item, semantic and operational equivalence of the Brazilian version of EMBU to measure parental educational practices in adolescents. Cad Saude Publica 2014;30:1633-1638. 